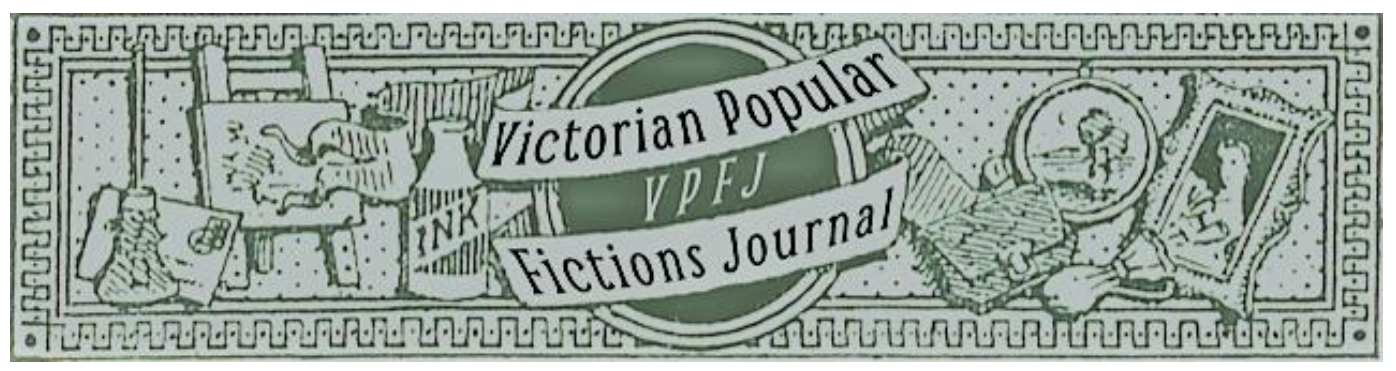

\title{
"His most ardent desire is to be ranked with Zola and rejected by Mudie": Gerard; or The World the Flesh and the Devil - M. E. Braddon's Fin-de-Siècle Faustian Rewrite
}

\section{Janine Hatter}

\begin{abstract}
Faust's pact with the Devil and his subsequent decline into hedonism have been the basis for many rewritings and adaptations since Marlowe's Elizabethan tragedy. Mary Elizabeth Braddon's radical rewrite of the Faust myth from a fin-de-siècle perspective Gerard; or the World, the Flesh, and the Devil (1891) - updates the conflict between God and the Devil vying for man's soul into a non-supernatural tale to comment on fin-desiècle bourgeois materialism, atheism and decadence. Braddon draws on two source texts for her adaptation: Johann Wolfgang von Goethe's Faust: A Tragedy (1808) and Honoré de Balzac's La Peau de Chagrin (1831). Braddon's three main characters critique different, yet interconnecting, social issues: the dandy hypnotist, Justin Jermyn, warns of the dangers of increasing pseudo-scientific knowledge; the nouveau riches Gerard Hillersdon illustrates the harm done to both mind and body when religious doubt and material culture collide; and the fallen woman, Hester, comments on women's agitation for social change. Overall, Braddon's combination novel transcends her trademark sensationalism to become an excellent example of the female aesthetic novel.
\end{abstract}

\section{Key Words}

Mary Elizabeth Braddon; Faust; Balzac; Goethe; adaptation; rewriting; fin de siècle; decadence; hypnotism; fallen woman

Date of acceptance: 18 June 2019

Date of Publication: 10 July 2019

Double Blind Peer Reviewed

\section{Recommended Citation:}

Hatter, Janine. 2019. "'His most ardent desire is to be ranked with Zola and rejected by Mudie': Gerard; or The World the Flesh and the Devil - M. E. Braddon's Fin-de-Siècle Faustian Rewrite." Victorian Popular Fictions 1.1: 35-56.

ISSN: 2632-4253 (online).

DOI: https://doi.org/10.46911/HMTW2498 


\title{
"His most ardent desire is to be ranked with Zola and rejected by Mudie": \\ Gerard; or The World the Flesh and the Devil - M. E. Braddon's Fin-de-Siècle Faustian Rewrite
}

\author{
Janine Hatter
}

\section{Introduction}

Gerard; or the World, the Flesh and the Devil (1891) is Mary Elizabeth Braddon's radical rewrite of the Faust myth from a fin-de-siècle perspective. As an updating of Faust's pact with the Devil and his subsequent decline into hedonism, Gerard contributes to a long-standing tradition of the Faustian myth from Christopher Marlowe's Elizabethan tragedy, through Goethe's tragic reinterpretation and G. W. M. Reynold's Gothic Romance Faust: A Romance of the Secret Tribunals (1847) in the early nineteenth century, to Marie Corelli's melodramatic ${ }^{1}$ The Sorrows of Satan (1895) that was also published in the fin de siècle. Yet to be critically examined for its influences, updates and impact on the Faust myth, Braddon's novel has two specific source texts: Johann Wolfgang von Goethe's Faust: A Tragedy (1808) and Honoré de Balzac's La Peau de Chagrin (The Wild Ass's Skin, 1831). Both of these texts are explicitly engaged with, denoting a change in Braddon's writing practices. In line with her broader fin-desiècle writing, Braddon updates Faust's struggle between divine knowledge and more human pleasures and the supernaturalism of her two source texts to produce a non-supernatural tale that explores, as one contemporary critic describes it, "the agnostic's sense of the shortness of life and the futility of riches" ("Our Library Table" 1891: 3). Braddon's main themes of increasing pseudo-scientific knowledge, religious doubt and women's agitation for social change produce a combination novel that transcends her trademark sensationalism to become an excellent example of the female aesthetic novel.

\footnotetext{
1 'Melodramatic' as described by Annette Federico in her text, Idol of Suburbia: Marie Corelli and Late-Victorian Literary Culture (2000: 76). Comparing Gerard and Sorrows reveals that both have protagonists who are financially troubled writers, both draw heavily on intertextuality to inform their rewriting of the Faust myth and both comment on the religious and moral downturn of the fin de siècle. The contrast comes as they were published either side of the collapse of the three volume novel, and they also take opposite sides on the religious debate. Braddon's novel examines the effect on society and the individual if God is presumed dead, while Corelli declares he is 'vibrantly alive' (Keating 1996: xix).
} 
The World, the Flesh and the Devil ${ }^{2}$ was first published as a syndicated serial in the Cork Constitution from 3 January 1891, followed by the Weekly Northern Whig and the Sheffield Weekly Telegraph from 10 January, and was serialised as late as 6 June in the Burnley Express. Braddon had been systematically syndicating her novels in newspapers in the major industrial cities of the north (including Ireland) since 1873 (Law 2000: 43). Newspapers, rather than fiction magazines, meant Braddon's novels were disseminated to a wider geographical and social demographic than just her London readership, spreading her popular fiction's influence on a wider scale. Following the novel's newspaper serialisation, the three volume edition, published by her long-term publishers Simpkin, Marshall, Hamilton \& Co in September 1891, added the name Gerard to the title, moving the emphasis to an individual protagonist and away from the more generic themes of the book. The $2 \mathrm{~s}$ and $2 / 6$ single volume editions were advertised in the London Illustrated News on 2 April 1892, with the yellowback edition, whose front cover emphasised the religious theme, being released later that year (Image 1); Gerard moved into single volume format within six months quick, but not extraordinary during this period. Gerard therefore followed Braddon's traditional publishing route. Overall, the novel was a good seller, maintaining Braddon's status as a well-established, widely-read popular fiction author.

The novel's reception was a critical success, with reviews printed in both the London periodicals and the northern newspapers. The Athenaeum's first review on 26 September 1891 (reprinted in the Bristol Mercury two days later) noted that Gerard had running through it "the same feeling which breathes through the lament of the Preacher," indicating that the atheist's religious turmoil was their main interest, though the reviewer was dismayed that the novel "touches only the outermost fringe of the supernatural" ("Literary Gossip" 1891: 420). On the same day, the Dundee Courier published its review that also commented upon the "religious fervour [that] plays a considerable part" in the narrative, as well as expressing their concern that they "hope[d] Miss Braddon is not growing moody" because the novel is like "a mournful portent of a novelist's repentance" ("Our London Letter" 1891: 5). This reviewer notes a change in tone from Braddon's earlier works, commenting upon the more serious subject matter she was tackling. Dedicating a full column to Gerard on 2 and 9 April 1892, The Athenaeum collates reviews from a range of geographical and social demographic sources, including the Queen, Perthshire Advertiser, Scotsman, Liverpool Daily Post, Literary World, and Leeds Mercury. Praise ranges from Braddon's “ingenuity, her method, her lavishness of decoration," to her ability to be "true in her delineations of human passion," and though Gerard includes "an undercurrent of pessimism" one reviewer read the novel 'with a spell-bound fascination' ("Miss Braddon's Latest Novel" 1892: 448). These reviews realise the themes of contemporary

\footnotetext{
${ }^{2}$ Braddon's novel is not to be confused with the 1959 American science fiction film of the same name, written and directed by Ranald MacDougall. Starring Harry Belafonte, the film is a post-apocalyptic narrative based on The Purple Cloud (1901) by M. P. Shiel (Shaw 1960: 228).
} 
culture's bourgeois materialism and the religious downturn of the fin de siècle, as well as Gerard's success at being a novel of character, a goal Braddon had been striving for since the early 1860s. These reviews confirm that Braddon's "ultrasensational ... period had gone by," particularly as Gerard's depiction of society is compared to Zola and Ibsen in regards to people's "illicit cravings" to "eat, drink, and be merry, for to-morrow we die!'” (448).

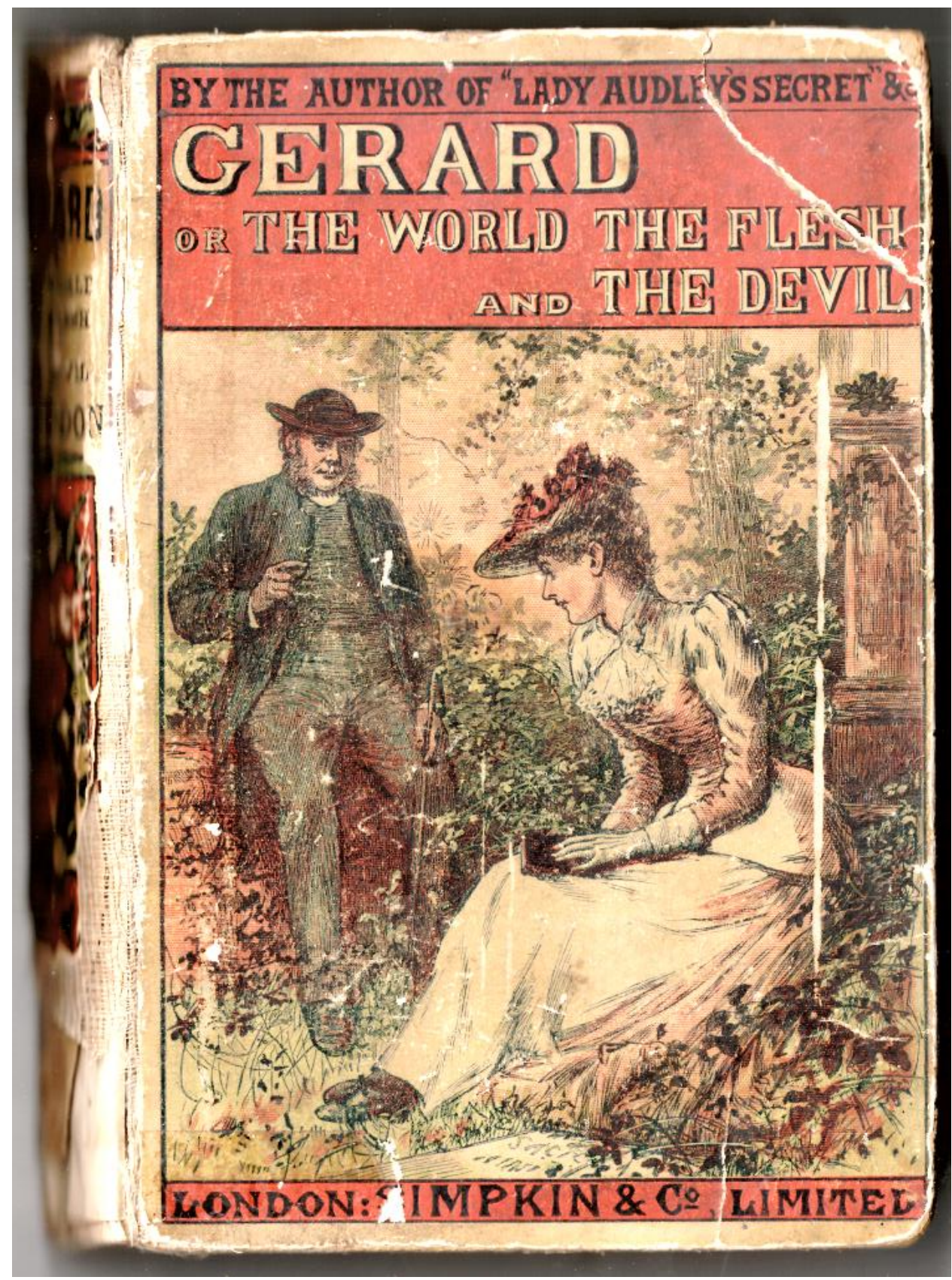

Image 1: Gerard; or, the World, the Flesh and the Devil, 1891, yellowback front cover, Janine Hatter's personal collection 


\section{Braddon's Rewriting and Intertextual Publishing History}

From her first published works in the 1860s, Braddon has been well-known for her rewritings of classic texts both by contemporaneous critics and in modern critical discourse. Braddon's contemporaries condemned these rewritings throughout her career, calling it plagiarism. While she decried these accusations publically, she admits in a letter to her mentor, Edward Bulwer Lytton, in March 1866 that she had "no marked character of [her] own - but reflect[ed] the ideas of other people in a pale kind of way" (1974: 135). Potentially a self-depreciating comment made to her literary hero, Braddon nevertheless demonstrates concerns about her own merit as a career author and the strategies she used; namely her literary rewritings. Contemporary critics were able to note her literary sources: The Doctor's Wife (1864) was based upon Gustave Flaubert's Madam Bovary (1857), while Circe (1867) was based on Octave Feuillet's play Dahlia (1857). ${ }^{3}$ Braddon also rewrote her own texts for different readerships, as another literary production strategy (for instance, her lower-class penny fiction serial The Outcasts became the middle-class triple decker Henry Dunbar ${ }^{4}$ ). While Victorian literary critics were quick to seize any similarity between texts and decry it as plagiarism, this practice did not reflect the amount of wit, imagination and originality involved by the author to produce these intertextual rewritings; nor did they take into account the pressure Braddon was under to produce work to satisfy her demanding publishers and readership.

Braddon exploited her considerable literary knowledge by steeping her novels in intertextual references from Greek myths to her real-life literary heroes, demonstrating that she engaged with a wide range of genres and high-brow writers to lift her own literary status. Braddon self-reflexively discusses this through her mouthpiece Sigismund Smith, a successful novelist, in The Doctor's Wife (1864). Smith established the new genre of the "combination novel" by noting that:

when you're doing four great stories a week for the public that must have a continuous flow of incident, you can't be quiet as original as a strict sense of honour might prompt you to be ... Don't empty one man's pocket, but take a little

${ }^{3}$ Fredrick Greenwood in particular was quick to vilify her, under her pen name "Babington White," for this latter appropriation in several articles in The Pall Mall Gazette. For full details see: Wolff, 1979: 207-16.

${ }^{4}$ The Outcasts (1863-4) - which featured two murders, a fatal horse-racing accident and a number of natural deaths - became Henry Dunbar (1864), for which Braddon reduced the number of murders to one (and set it off-stage), removed the slum locations to just leave the London banking house and country estates, and changed the emphasis of the title from anonymous marginalised multitudes to the individual subject in line with the Bildungsroman (Beller 2015: 287). However, the middle-class critics vilified Braddon for making her triple decker too tame; their taste, just like that of her lower-class readers, was for sensation. In his biography of Braddon, Wolff notes that Henry Dunbar was 'one of MEB's greatest financial successes' though (1979: 158), proving despite what the critics said, Braddon was on the pulse of the literary marketplace. 
bit all round. The combination novel enables a young author to present his public with all the brightest flowers of fiction neatly arranged into every variety of garland. I'm doing a combination novel now - the Heart of Midlothian and the Wandering Jew.

(Braddon [1864] 1998: 45)

As Andrew King notes, within The Doctor's Wife, the combination novel is defined as the fundamental writing technique of an author of a mass-market novel (2009: 79), while Albert Sears notes that it "represents a blend of fictional modes [allowing a writer] to capture a different market of readers, especially when her reputation is already constricted" - as Braddon's was to sensationalism (2006: 44). Thus, while Sears focuses on the combination novel's effect on Braddon's reader reception, I, in line with King, focus on Braddon's writing processes for a combination novel - in this instance a combination of Goethe's Faust and Balzac's La Peau de Chagrin.

The combination novel is distinct from plagiarism, which was a topical debate during the 1880s. As Andrew Lang, a nineteenth-century author and critic noted, plagiarism was almost impossible: "If you merely used old ideas (and there are no new ideas), and so produce a fresh combination, a fresh whole, you are not a plagiarist at all" (1887: 835, emphasis added). The "stock-in-trade" characteristics of genre, motifs and characterisation cannot be "invented over and over again" (836); instead, a good writer should "make what is a thoroughly original use of it" (838). Thus, the combination novel as a genre sidestepped plagiarism accusations because of its very nature. In fact, the combination novel approach allowed Braddon to keep up with the times, because, as the Sporting Gazette noted, Braddon had an 'inventive imagination' that made each new novel "wholly different ... yet fully as interesting" as the last ("Literature" 1865: 786). It is this contrast in reviews that Braddon had tried to bridge from the 1860s; however by the late 1880s-1890s she was in a more financially secure and critically respected position and so was better placed to achieve her goal.

Building on his analysis of combination novels and their relationship to plagiarism in June 1887, Lang also examines another type of combination in the November 1887 issue of The Contemporary Review: the "Realism and Romance" debate - which Braddon implicitly engaged with. Lang notes that over the Atlantic raged an argument regarding not the quality of books, but their value to their readers, which should be based on "their relative merits" (1887: 690). He continues that "it will always be possible to combine the interest of narrative and of adventure with the interest of character" (690). This combination is how Braddon developed her 1890s writing, balancing both the Romance of her plots, with the Realist interest in character development - something her literary critics in the 1860s vilified her for not doing (Oliphant 1862 \& 1867; Mansel 1863; Rae 1865). As Lang concludes, "it is apparent that no single genre of novel is in ... the near future, to be a lonely literary sultan, lording it without rival over the circulating libraries" (690). While there may not be a single genre that can achieve this goal, Braddon maintained her status as "the 'Queen of the Circulating 
Libraries" into the 1880s-90s (Walbank 1950: 122), demonstrating that one author writing in multiple genres over a thirty year period could.

Having ceased her writing strategy of two novels a year (one high-brow to appease her critics and one popular to please her readership) in the late 1880s, Braddon focused her efforts on producing one novel of high quality per year. As noted above, "high quality" for Braddon meant a novel of character, as confirmed by the reference to the aspiring writer, Mr. Gambier, in Gerard. As this article's title notes: "His most ardent desire is to be ranked with Zola and rejected by Mudie" (Braddon [1891] 2009: 182), and Braddon specifically achieved this with Gerard through her open and direct reading and referencing of French and German fiction. What was in the 1860 s considered "obnoxious" and "improper" (M. 1867: 78, 80), by the 1890s was established as a good seller in Britain, ${ }^{5}$ thus society (i.e. her readership and the literary critics) was finally placed to accept Braddon's more Zola-esqe writing and have it not be rejected by Mudie especially because she wanted the income from his circulating library readers. ${ }^{6}$ As Jennifer Carnell notes, Faust and La Peau de Chagrin are "fully acknowledged within the text as Gerard Hillersdon constantly compares his experiences with the heroes of the two source works" (Carnell 2000: 212). Even if it led to critics to bemoan that she "kept reminding her readers of what she was trying to do, and making it difficult for them to ignore her inability to do it" (Wolff 1979: 348), the fact that Braddon did not hide that she was drawing on Continental literature for this novel reveals a change in tactics when rewriting her source materials as she was surer of herself and her literary standing.

\section{Rewriting and Updating the Faust Myth}

To explain how Braddon rewrites the Faust myth for her fin-de-siècle readership, we must now compare a synopsis of Marlowe's The Tragical History of the Life and Death of Doctor Faustus, Goethe's Faust, Balzac's La Peau de Chagrin and Braddon's Gerard in order to examine their cross-related themes of the (non)supernatural, science, and seduction. Marlowe's Elizabethan tragedy, Doctor Faustus, has two versions. They are both written in blank verse and prose, but the 1604 version has thirteen scenes, while the 1616 version has twenty. They both

\footnotetext{
${ }^{5}$ In certain cases, Continental literature still had a reputation for being shocking. For instance, Henry Vizetelly was prosecuted twice for obscenity in 1888 and 1889 for publishing translations of Zola's Le Terre, because the novel outraged the conservative bourgeois (Ritschel 2017: 38-9).

${ }^{6}$ Mudie's and W. H. Smith's circulating libraries fell out of favour with publishers in the mid-1890s because they demanded a reduction in price per volume for the books they bought, and a delay in publishing the cheaper one-volume versions, leading publishers to argue that they would not be able to offer their writers the wages they were used to. The collapse of the triple decker came around 1895, making Gerard one of Braddon's last three-volume novels; always on the pulse of the literary marketplace, Braddon had two one-volume novels written ready for publication when it occurred (Kucich and Taylor 2010: 6-9; Wolff 1979: 355-60).
} 
follow the same basic plot: Doctor Faustus, a well-respected German scholar with a thirst for ultimate knowledge, turns to magic in order to expand his understanding of the universe. He summons Mephastophilis, a devil, and casts a bargain with him - Faustus offers his soul to Lucifer in exchange for twenty-four years of service from Mephastophilis. Having accepted the bargain, Lucifer and Mephastophilis parade the Seven Deadly Sins in front of Faustus to display their skills and assuage his doubts. Faustus uses Mephastophilis to play tricks on people, like the Pope, the court of Charles V and a horse dealer, and he travels across Europe gaining fame. Over the narrative, Faustus conjures up images of Alexander the Great and the beautiful Helen of Troy, as well as fresh grapes in the middle of winter, as demonstrations of his power. As the twenty-fourth year approaches, Faustus dreads his impending death and begs for mercy, but it is too late - devils appear and carry his soul to hell.

Goethe's version of Faust is a play written in two parts. Part One outlines the conflict for Faust's soul. Mephistopheles makes a wager with God, saying that he can lure Faust's quest for knowledge away from the righteous path. Faust, frustrated with his lack of progress, contemplates suicide, but rejects the idea as he hears the Easter bells ringing. On returning from the celebrations, the stray dog that has followed him morphs into Mephistopheles who offers to do as Faust wishes on earth, while Faust will serve him in Hell. Later, Faust meets Margaret (also called Gretchen) whom he seduces. Goethe's famous scene of Gretchen dreaming of Faust at her spinning wheel was influential in the arts, inspiring paintings by Ary Scheffer and James Tissot (Matyjaszkiewicz 1985: 88). Gretchen becomes pregnant, drowns their illegitimate child, is convicted of infanticide and condemned to death. Faust tries to save her, but she refuses to escape the prison. Voices from Heaven announce that Gretchen shall be saved just as Faust and Mephistopheles escape. Part Two continues Faust's adventures and quests for knowledge. Ultimately, Faust goes to Heaven through the intercession of Margaret and the Virgin. Goethe's text, Part One specifically, was variously set to music by Franz Schubert in 1814, Richard Wagner in 1839-40, Franz Liszt in 1857 and made into an opera by Charles Gounod in 1859 (Bodley 2017), continuing the spread of the Faust myth, and Goethe's version in particular, throughout the nineteenth century.

Balzac's La Peau de Chagrin has three parts and centres on Raphael de Valentin, a young aristocrat who has gambled all of his money away in the Palais Royal in Paris. In Part One, he contemplates suicide by throwing himself into the Seine, but before he does so, he visits an antique shop full of bizarre objects. One of these curiosities is a shagreen, a piece of rawhide with magical properties that grants its owner's wishes, but which subsequently shrinks, hastening its owner's death. Raphael's first wish is to have a splendid Bacchanalian feast, which comes true. Part Two is a flashback in which Raphael recalls his time as a poor student, living with his landlady and her daughter, Pauline. Raphael immerses himself in high society and tries but fails to win the heart of Countess Foedora, so he becomes miserable - which is where Part One began. Part Three is set several years after Part One, and finds Raphael having used the talisman to wish for riches and as a result he is in declining health. He tries to destroy the shagreen 
using chemistry and physics, but to no avail. Pauline re-enters his life, declares her love for him and reignites Raphael's desire for her. Realising that his desire for her will kill him, Pauline attempts suicide. To stop her, Raphael expresses his desire to die in her arms and they consummate their love, which leads to his death. A comparison of Goethe and Balzac reveals how both male protagonists' quests for knowledge lead them into the supernatural realm, and in the end women selfsacrifice to grant the man they love what he wants.

Braddon's rewrite, Gerard, begins by introducing Gerard Hillersdon as a financially troubled writer, who must balance the news he will die within a few years unless he leads a sedate life with a recent inheritance of two million pounds. Gerard loves Edith Champion, but he must wait for her: first because she is married to a wealthy banker, a marriage arranged by her family, and, after the banker's death through, her year's mourning. During that time Gerard meets Justin Jermyn - Braddon's "fate-reader" - who shows him a vision of a beautiful woman working at a spinning-wheel, much like Goethe's Gretchen. Gerard eventually finds this woman, Hester Davenport, and befriends her. Her father is a recovering drunk, whom Gerard buys off in order to convince Hester to become an atheist and his mistress. Hester becomes pregnant, just as Edith's year of mourning ends, and Gerard abandons Hester for Edith. Edith, seeing the emotional and physical wreck Gerard has become due to the turmoil of his predicament, dissolves their union, just as Gerard learns that Hester has attempted suicide, has drowned their baby and has lost her mind. He returns to Hester, who eventually recovers, is absolved of the murder of her child, and marries Gerard who himself dies at the end of novel.

Braddon spent a long time contemplating her rewrite of Faust with La Peau de Chagrin. Wolff notes Braddon "had read Faust in a French translation - almost surely that of Gérard de Nerval [both first and second parts] - and Lewes's life of Goethe" as early as 1866 (1979: 182), while Braddon wrote in her letter to Edward Bulwer Lytton in May 1866 that during this period she was "reading very little ... - only a few French novels, Balzac \& Soulié" (1974: 14), and that she will "devote [herself] to a course of [Bulwer's] books, \& Balzac's for the next three months" (27). In 1872, she returned to these novels when she noted to Bulwer that "[h]ad [she] the pen of a critic [she] should dearly like to write an article upon [his novel A Strange Story] \& Balzac's Peau de Chagrin - the only two great novels I know of, of a purely supernatural character" (157). Discussing French literature and supernatural fiction with Bulwer over five years later, indicates that they held a prolonged interest for her, more still because it was not until 1891 , nearly thirty years later, that she attempted this rewriting.

What is most surprising, given Braddon's praise of the original's "purely supernatural character," is that Gerard's chief novelty is that it is written from a non-supernatural perspective. Instead, Braddon uses the cultural, scientific, religious and political changes that were taking place in the $1880 \mathrm{~s}$ as a prompt to write her own engaging non-supernatural narrative, which was filled with just as much controversy and peril as the "forbidden knowledge" would have held for 
Faust. $^{7}$ Equally, the employment of these non-supernatural devices may have allowed her to finally engage with themes and topics that she could not have dared to deal with in the 1860 s. Talia Schaffer, in her critical text The Forgotten Female Aesthetes: Literary Culture in Late-Victorian England (2000), postulates that Braddon's sensation fiction was a precursor to the later aesthetic movement, and that she influenced writers such as Netta Syrett, Violet Fane and Ouida and their 1890s novels that promoted female emancipation and sexual liberation (36-8). Nevertheless we must consider that Braddon was still writing in the 1890s and beyond, and as previously noted, she was frequently praised for keeping up with the times and so did not let the new literary movements of decadence and aestheticism pass her by. Braddon may have pioneered the way for other female writers, but she also built upon her own writing to engage in fin-de-siècle aesthetic narratives of her own. Schaffer goes on to delineate between two types of aestheticism: that associated with The Yellow Book which was tailored to an elite male audience and utilised careful, condensed language; and that which was "popular, based in material culture," was "designed for a female readership," and "allowed [women] to write the pretty visual descriptions that critics liked, yet ... was also avant-garde enough to permit a new range of daring topics" (2-5). While I would not position Braddon as a female aesthete herself, I position her Faust rewriting as an example of this second kind of aestheticism. Gerard is a female aesthetic novel that updates the Faust myth by deliberately engaging with fin-desiècle fears of decreasing religious belief and increasing scientific knowledge, bourgeois material culture, female sexual liberation and illegitimacy.

\section{The Explained Supernatural: Justin Jermyn as Mephistopheles}

One of the key adaptations Braddon made in Gerard is the pseudo-scientific ${ }^{8}$ explanation for what was the work of the devil in Marlowe's and Goethe's texts. As Schaffer has noted:

[t]he 1890s sensation novel differed from the 1860s genre because it usually centered [sic] around the spiritual rather than the criminal; a character's illicit knowledge often came through hypnosis or telepathy.

(Schaffer 2000: 37)

7 This non-supernatural angle was topical at the time due to the furore around Spiritualism, which, because of the Fox sisters' hoax mediumship was undergoing a crisis of faith that resulted in a questioning of the supernatural more broadly (Weisberg 2004: Chapter 17). Thus, with Gerard, Braddon is silently countering the Spiritualist movement to confirm that mediums are fraudulent beings who prey upon people's pain and suffering for their own advantage.

${ }^{8}$ Though there is a "disciplinary separation through which magnetism [or mesmerism] is envisaged as a mere pseudoscience and hypnotism a pioneering form of protopsychology" (i.e. a science) (Hughes 2019: 13), the feats performed by Jermyn are not aligned with any scientific discourse and will thus be included with the discussion of pseudo-sciences. 
Braddon thus kept up with the times because the supernatural Mephistopheles is recast as the fate-reader Justin Jermyn. Jermyn learns people's secrets (their "illicit knowledge") by hypnotising them (his own "illicit knowledge"), and uses this information against them by turning it to his advantage. For instance, by laying "his hand on Gerard's shoulder with a friendly movement" and using the "slow music of [his] voice" (407), Jermyn hypnotises Gerard. Under hypnosis, Gerard appoints Jermyn his "residuary legatee" - the sole beneficiary of his estate (408). Gerard's valet witnesses the document and trusts Jermyn as he "has a scientific air, and was doubtless half a doctor" (413), blurring the boundaries of supernatural influence, quackery and scientific practice.

The earlier teachings of William Carpenter, specifically his lecture "On the Influence of Suggestion in Modifying and Directing Muscular Movement, Independently of Volition" (1852) where he discusses mesmerism's effects on a person, and the later development of hypnotism as a medical practice, were both widely influential on literature, George du Maurier's villainous Svengali in Trilby (1894) being perhaps the best known exploitative hypnotist. ${ }^{9}$ Hypnotism was reinvented in France in the 1850s by James Braid and Pierre Janet, with the neurologists Georges Gilles de la Charcot and Jean-Martin Tourette later developing the theory of "criminal hypnotism," which was brought to the public attention between 1888-1890, when a series of hypnosis-related criminal cases took place (Bogousslavsky et al. 2009: 196-8). This raised the issue of potentially dangerous uses of hypnotism just a few years before Braddon's novel was published. I would argue, therefore that Gerard succeeds as a Faust rewriting, because Braddon adapts it into a non-supernatural text; Jermyn is not the devil incarnate, but a man who has no conscience, who uses the scientific practice of hypnotism as the modern equivalent of gaining Faustian knowledge to improve his social position. ${ }^{10}$

Jermyn is also a dandy, a threatening and seductive fin-de-siècle presence. As Rhonda Garelick notes: "Dandyism is itself a performance, the performance of a highly stylized, painstakingly constructed self, a solipsistic social icon ... whose goal was to ... provoke reaction in others through the suppression of the "natural""

\footnotetext{
${ }^{9}$ In the stage version of Trilby by Paul Potter, first performed the year after the novel was published, Svengali is described as using "“that devil's trick - hypnotism" (Potter 1996: 216).

${ }^{10}$ Braddon's later 1896 short story "The Good Lady Ducayne," published in The Strand Magazine, uses this same non-supernatural technique. An old woman who wants to live forever hires a doctor who has no conscience to drain her companions' blood and transfuse them into herself, revealing a scientific explanation for a supposedly supernatural (vampiric) occurrence. The doctor abuses his professional practice to keep his patient alive in order to advance his own social position, while the old woman preys upon vulnerable women looking for work to satisfy her own personal desires. This places "The Good Lady Ducayne" and Gerard in what Diana Wallace defines as the Radcliffean Female or Rational Gothic mode of the explained supernatural (2009), demonstrating Braddon's continuing of a female popular genre. See my article in Supernatural Studies for more details on "The Good Lady Ducayne."
} 
(1998: 3). Jermyn's fate-reading is nothing if not a highly stylized performance, ${ }^{11}$ and it is this "suppression of the "natural" that leads to the confusion of the supernatural or non-supernatural source of his power. This is further noted by other people's multiple descriptions of Jermyn's profession, that of "thoughtreader" (Braddon [1891] 2009: 13), "mystery man" (13), "imposter" (14), "FateRevealer" (15), "wizard" (17), "fortune teller" (19), "sorcerer" (25), "shallow trickster" (50), "prophet" (194), "necromancer" (194), and even "private detective" (194). ${ }^{12}$ Not only can characters not classify who he is, they also cannot define how he reads their fates: he is described by the narrator as a "creature gifted with superhuman powers" (14), but his skills are debated by other characters as "“absolute divination"” (13), “"a trick”" (13), “"occult powers"” (14), “"poor gifts"” (14), “"a keener vision"” (16) or a "doubtful science" (18). Jermyn himself defines his skill as "the power of insight" (33). Drawing upon religion, the occult, the uncanny, science, criminals and their investigators, each of these references testify to Jermyn's ambiguous, deliberately secretive personality aligning him with a confidence man undertaking a trick.

This change from the supernatural to the natural, according to Wolff, should play to Braddon's strengths because "[t]he supernatural was, as she had thought in her youth, unsuited to her talents" (1979: 348). Nevertheless, the text's separation from its supernatural origins was lamented by contemporary reviewers as a weakness of the rewrite. For instance, The Daily News on 5 September 1891 notes: "The story is a sad one, and the machinery, which ... reproduces the central idea of Balzac's 'Peau de Chagrin,' touches only the outermost fringe of the supernatural" ("The Morning's News": 5), while The Pall Mall Gazette comments on Braddon's use of the "sham supernatural which is mixed up with hypnotism and thought-reading ... Mephistopheles is neither natural nor supernatural" ("Some Recent Novels": 3). According to contemporary reviewers, it was Braddon's updating of the supernatural to the pseudo-scientific that weakened the narrative, with critics seemingly disappointed in a Faust rewrite that side-lined diabolical aspects. However, it is this aspect of the rewrite that allows the novel to transcend the Faust tradition from Marlowe onwards, and Balzac's source text, to stand on its own merits. Braddon works in the liminal space between the natural and the supernatural to create her villain. This change is significant because it means that Braddon's more open and direct social commentary on the moral decline and increased material culture of the era is not hidden behind a layer of supernatural tricks that can be dismissed as the work of the devil; Jermyn's quest for Gerard's money derives specifically from Jermyn's own fancy, ego and decadence. ${ }^{13}$ Jermyn's biggest $\sin$ is sloth; he meanders through life, gambling his

${ }^{11}$ The first instance of Jermyn's fate-reading in the novel is at a party where guests enter a private room for a meeting with him; it is part of the evening's entertainment.

${ }^{12}$ In the era of Sherlock Holmes this phrasing is significant in drawing comparisons between Jermyn and Holmes regarding their characters, processes of procuring information, and their motivations in discovering people's secrets. While Holmes uses his knowledge to solve mysteries, Jermyn uses his knowledge for person gain.

${ }^{13}$ Each of these words has a technical meaning within English Literature as a discipline: "fancy" as Coleridgean, "ego" as a psychological term as defined below, and 
way to his next adventure, hoping a big score will cross his path, rather than assert himself to do something worthwhile.

The religious turmoil of the fin de siècle is a key instigator of this change within the rewrite. As Ian Watt notes, "[t]he Faust myth arose when the development of Christian thought had polarized the human and the supernatural worlds into a conflict between good and evil" in the early sixteenth century (Watt 1996: 12), while Braddon's rewriting of the Faust myth came when belief in God was waning, there was a decline in churchgoing, and "a new departure in the religion of the uncanny" (Braddon 2009: 13) - such as hypnotism. The conflict was no longer between God and the Devil, but the belief in God or no God and this led to a decline in supernatural beliefs; there could be no ghosts or no afterlife, if there was no God. Thus, atheism led to an increased pressure on psychology and morality to govern behaviour. This lack of belief in the otherworldly is brought to the fore when Gerard questions Jermyn on the vision he produced of Hester sitting at the spinning wheel. Not caring if it was 'hypnotic' or produced by "mechanical means" at the time (41), Jermyn later states Gerard " "make[s] no allowance for the submerged identity - that inner ego beneath the outer husk of existence - that hidden nature which keeps its fancies and thoughts locked in darkness" (138). Braddon's use of "submerged identity"14 and "inner ego" 15 demonstrate how up-to-date she was on psychological developments of the mind in regards to psychology as an emerging discipline, ${ }^{16}$ and hypnotism specifically. According to Jermyn, Gerard's vision was a psychological manifestation of his inner desires, which could relate it to the psychological ghost story as epitomised by Henry James's later novel The Turn of the Screw (1898); but instead, the novel aligns Jermyn's power as a hypnotic hold that draws out Gerard's subconscious desires to the practice of psychology.

"decadence" as a literary movement, as discussed by Arthur Symons in "The Decadent Movement in Literature" (1893) Harper's Bazaar.

${ }^{14}$ This term is used in The Spectator's article entitled "Planché's Extravaganzas" (1880) in which the author details how actors have to put a part of themselves into their performance, or else their "submerged identity" produces "mimicry" not "acting" (374). Braddon had been an actress for eight years in the 1850s (Carnell 2000: 13), and would have understood this meaning. This theatrical use of the term also supports my argument of Jermyn's dandy performance.

${ }^{15}$ Herbert Spencer established the ego in terms of "belief" - logical acts of the intellect predicated on the assertion that something is - earlier in the century (1855: 14), denoting ego to mean a belief in the self; the "I." "Inner ego" suggests a split in the self, an outward and an inward persona that can hide underlying desires and motivations.

${ }^{16}$ Psychology originally referred to "the study or consideration of the soul or spirit" (OED), but by the mid-nineteenth century psychology as a discipline had developed as "a scientific study of the nature, functioning, and development of the human mind, including the faculties of reason, emotion, perception, communication, etc." (OED). It is this wider definition of the discipline that Braddon utilises in Gerard. 
Pre-Freudian in her terminology, ${ }^{17}$ Braddon's depiction of Jermyn's hypnotism of Gerard closely follows the practice and teachings of Charcot (mentioned above). As the Glasgow Herald in 1888 asserted, certain types of people were more susceptible to hypnotism than others:

the nervous, high-strung idealistic temperament is that on which the mesmerist operates with a fair chance of inducing the hypnotic condition. Contrariwise, it is the "steady and stolidy" person .... The unimaginative, unimpressionable individual - who defeats all attempts to influence his existence outside of the sphere of his own will. (“Curiosities of Mesmerism II" 1888: 9)

William Hughes, quoting the above, concludes that "susceptibility to hypnotism would appear to be yet another likely decadent symptom of fin de siècle aestheticism" (2015: 215). Thus, it is Gerard's own decadent nature (as discussed below) that makes him susceptible to Jermyn's influence. In fact, Jermyn's hypnotism of Gerard early in the novel to produce the vision of Hester at the spinning wheel potentially made Gerard more susceptible to being hypnotised later on, when Gerard fraudulently signs his will in favour of Jermyn. As Hughes' research reveals, hypnotism was believed to leave one more susceptible to "“nervous symptoms"” or "unforeseen neurosis" (216), and so throughout most of the novel Gerard is in a weakened mental and physical state. Braddon's engagement with the psychological and hypnotic theories of Charcot, then, adds a different dimension to the Faustian bargain, as well as demonstrating that Braddon as a popular writer is not isolated from the learned, but is participating in it; influencing how her readers engage with scientific thinking. Instead of Mephistopheles tempting Faust with the world's secrets, Jermyn tempts Gerard with his own personal hidden desires. Braddon makes her rewriting more grounded, more relatable to her readers. Braddon does not need a supernatural demon to tempt people to $\sin$; $\sin$ is part of everyday life.

\section{The Medical Talisman: Gerard as Faust}

Another of the key adaptations Braddon made to the Faust myth in the novel is changing Gerard's sin from pride (quest for knowledge) to covetousness (quest to fulfil human desires). Gerard's decadence and bourgeois cultural materialism are emphasised in the Queen's review, which notes:

In "Gerard" we soon find ourselves set round with all that pomp and circumstance of wealth which Miss Braddon sets forth with such a master hand. Gerard's

\footnotetext{
${ }^{17}$ Sigmund Freud only published his first text, On Aphasia, in 1891, the year Braddon published Gerard, while his second text, A Case of Successful Treatment by Hypnotism (1892) was published afterwards, and so Freud was not an influence on the novel.
} 
mansion adds another to the long list of the houses she has decorated with such delightful skill, and there are yet more toilets to move our envy and admiration.

(“Miss Braddon's Latest Novel" 1892: 448)

Gerard's decadence is a direct link to Balzac's novel, with many of the same settings repeated: the gambling house, a luxurious house party, and the theatre. These settings conjure associations of money, material excess, and artificiality key traits of the decadent movement. Gerard overall also fulfils Matthew Potolsky's definition of decadence as "mov[ing] within a recognisable network of canonical books, pervasive influences, recycled stories, erudite commentaries, and shared tastes" by being a rewrite in itself (2013: 5). The novel's decadence illustrates Braddon engaging with the fin-de-siècle fear of the study of human desire as the driver of society. The fin de siècle was a period of economic downturn bolstered by a rise in advertising to promote consumerism: desire was being promoted as the driver of progress. Regenia Gagnier, in "On the Insatiability of Human Wants: Economic and Aesthetic Man," describes the creation of "the universal man of insatiable consumer desires" during this period (1993: 125-6). Gerard, whose fortune means he can buy almost anything, embodies the "insatiable" "universal" man, because no matter how much he consumes or purchases, he is never satisfied.

Gerard's insatiable desires are emphasised by the novel's pseudo-medical narrative. Gerard's doctor warns of an early death due to "“weakness in both heart and lungs" (Braddon [1891] 2009: 107-8), so he must choose between a long, sedate existence, or a decadent, passionate, Dorian-esque shorter life. This is a significant contrast to Marlowe where Doctor Faustus receives twenty-four years' grace from the devil in which to utilise his knowledge before his soul is claimed, and to Raphael in La Peau de Chagrin, whose life shortens incrementally each time he makes a wish thereby shrinking his magical talisman. Instead, Gerard's life is curtailed by his quest for pleasure that derives from his own personal decadence and atheism; he chooses to "liv[e] faster, two heart-throbs for one"" (64). Again, Braddon taps into contemporary thought as the physician Havelock Ellis theorised that "Heart disease is common among criminals ... and the insane" (1890: 88), supporting the argument that Gerard's decadent nature could be influenced by his being hypnotised by Jermyn, as it weakened his mental state. Braddon once again resituates her novel and Gerard's dilemma firmly in the human realm; it is medicine's lack of answers for his own physical deterioration, not the Devil or a magical object, that tempts his decadent behaviour and edges him on to his inevitable death.

Building on Gerard's medical condition, this grounding in reality is supported by another pseudo-medical narrative. ${ }^{18}$ As previously mentioned, the only way for Gerard to extend his life, in order to enjoy his wealth, is to suppress his passions, desires and greed, but instead of this, he chooses "'to live, not to

\footnotetext{
${ }^{18}$ Just as Jermyn's lack of medical training meant he performed a pseudo-science, Gerard also has no training, and so I define his use of the talisman as a pseudo-medical practice.
} 
crawl" by making his every wish come true (39). To monitor his life span he creates his own Peau de Chagrin, which is not an enchanted skin that shrinks every time its owner's wishes come true as it is in Balzac's novel. Instead, Gerard "invent[s] for himself a gauge of his strength and nervine vitality" (160); he creates his own medical test. While in the best of health, Gerard draws a hidden talisman of a circle on the wall, and over the course of his life he traces this outline as a measure of his strength. Gerard calls this his "Chart of Life" (244). Gerard views his decreasing ability to draw these concentric circles as an indication of his draining life span - a physical demonstration of his degenerative condition. In Balzac's text, the Peau de Chagrin represents Raphael's life force, physical energy, his soul; Gerard notes in the same way that "[w]ith every quickening of the pulse above normal health, with every tumult of the heart, with every fever of the brain, fired by ardent hopes and conflicting wishes, a shred is torn off the fabric of a man's life" (39). Gerard's energy and life force is specifically linked to his body, the one material object he has control over. Eventually, he can only draw a straight line going significantly downwards, signalling his approaching death - providing a visible indication of his decline, without the need for a magic object.

Gerard is not an everyman figure with whom Braddon's readership should identify. As a failed fin-de-siècle writer, Gerard offers Braddon a specific character through whom she could portray an in-depth psychological study; he is, as the general population of women in the novel describe him, "so delightfully unlike any one else" (245). This psychological reading of Gerard is brought to the fore via the multiple intertextual references within the novel, specifically through the novels that Gerard reads: "He could not sleep, so he took down the Peau de Chagrin from the bookcase which held his limited library, composed of only that which he held choicest in literature ... Goethe's Faust, Heine's poetry and prose, Alfred de Musset, Owen Meredith, Villon, Gautier, Balzac, Baudelaire, Richepin; the literature of despair" (63-4). Mainly consisting of French literature these texts reveal "the bent of his mind" and how (64), even before his medical condition worsened, Gerard had a hedonistic nature. ${ }^{19}$ While Braddon's original title to the serial, The World, the Flesh and the Devil, draws upon Christian theology - these are the three threats of the soul as described by Thomas Aquinas - she adapts these threats for her growing secular readership to include supposedly immoral literature, seemingly verifying the point her critics had been chastising her with since the 1860 s.

However, not only does Braddon include these intertextual references, but she offers her readers a direct critical commentary on them, so there is no mistaking their significance. Gerard, after he tracks down and befriends Hester, teaches her his version of rational free thinking through literature. He notes that his sister, Lillian, gave Hester her "favourite poets and essayists [namely]

19 The link between scholars and writers as little better than lazy, reckless and base (almost dandy-like) themselves had been established as early as Marlowe's Doctor Faustus in the Middle Ages (Waddell 2000: 202), and so Braddon is drawing upon old traditions again, while updating them for the fin de siècle. 
Wordsworth, Hood, Longfellow, Adelaide Proctor, Jean Ingelow, Elizabeth Barrett Browning" (187); these are all "the poets within whose pages there is security from every evil image, from every rending of the curtain that shrouds life's darkest pictures" (187). Lillian only reads and recommends works her father allows, continuing the patriarchal dominance of women's lack of education and enlightenment of another way of life, while Gerard gives Hester a copy of Shelley's poetry so she can learn about "his gospel of revolt against law, human and divine" (187). He goes on to teach her about "the rude vehemence of the Elizabethan dramatists, the florid eloquence of Jeremy Taylor, the capricious brilliancy of De Quincey, the subtle wit of Lawrence Sterne" (243). The point is that while certain British and Continental literature can be deemed "immoral" reading because it can be used to corrupt, particularly young innocent women (Atkinson 2017: 19), it can also teach people how to "engage meaningfully with society" (20), as well as identify and therefore protect themselves from real-life sin and temptation - namely the hedonism and decadence associated with the upper classes. $^{20}$

\section{Saving the Fallen Woman: Hester as Gretchen}

In the opening scene of Goethe's Faust with the poet, clown and theatre director, the latter notes that women who attend the theatre "think they're at a party,/Parading round - it's all part of the show" (Goethe 1.119-20). Referring to

${ }^{20}$ Another intertextual link, this time not explicit and whose nature remains uncertain, is to Oscar Wilde's The Picture of Dorian Gray, which was published in July 1890 in Lippincott's Monthly Magazine, with the longer revised version published as a book in 1891. Dorian's reworking of the Faust story is commonly acknowledged (Kohl 2011: 162), and all three texts have similar overarching plots, Faust, Dorian and Gerard all centre on a male protagonist who is led into temptation by a Mephistopheles-figure, and who then seduces and ruins a woman's life: Gretchen, Sibyl Vane and Hester Davenport respectively. Wilde's character experiments with many vices, is influenced by French literature, hides his secret (a magically ageing painting) from view behind a curtain in the attic, eventually destroying it, which leads to his death as a rapidly aged man. Braddon's protagonist, as we have seen, reads Continental literature, hides his secret (his Chart of Life) from view behind a curtain, and then destroys it at the novel's conclusion - Gerard "tore [his talisman] into fragments and flung them into the wastepaper basket" (421) - which leads to his death. Similar in their explorations of society, philosophy and decadence, Braddon and her friend Wilde (Wolff 1979: 263), through opposing supernatural and non-supernatural means, come to the same conclusion: prioritising passion over contentment, desire over rational thought and greed over generosity may fulfil hedonistic individualism, but society's superficial cultural materialism means it is all to no avail. Overall, it is Gerard's preference for decadence over a morally virtuous life that weakens his heart and lungs and leads to his ultimate act of moral degeneracy: the seduction of Hester. While the resonances between the two novels may seem clear to us now, whether Wilde and Braddon had discussed and shared their plots in advance or whether the similarities between their novels are purely accidental remains uncertain. 
how women (and men) dressed up to go to the theatre, Goethe - managing director of the Weimar theatre (Brockett and Hildy 2006: 269) - emphasises that the audience was as much on display, or part of the spectacle, in the auditorium, as the actors on the stage; going to the theatre to see and to be seen was part of the social ritual. However, by the end of the nineteenth century the parts women were playing were changing, and while Braddon remains faithful to Goethe's version of the Faustian myth when she depicts his fallen woman, it also illustrates her most radical adaptation of her source material. Hester may be a "'modern Gretchen' but she is also 'a poor little sempstress slaving from dawn to dark for daily bread, as beautiful as a Greek goddess, and virtuous enough to prefer poverty to degradation. There is your true type of a nineteenth-century Gretchen"' (36). Seamstresses were singled out by Braddon as an occupation to illustrate this point because they were seen as being at risk of slipping downwards into prostitution in the popular consciousness. Seamstress were brought to the fore of the social, political, and economic consciousness in 1843 by Thomas Hood's poem "The Song of the Shirt," published in Punch, and considered in the "Second Report of the Children's Employment Commission" (1843) as suffering from harsh working and living conditions. As a result, seamstresses were associated with putting female bodies on display, and their necessity to walk the streets late at night after the light had gone to work by related them to the male gaze, making them more vulnerable to male advances (Alexander 2003: 202); they were popularly considered "alone and defenceless, without the protection of a husband, a family, or friends" (Edelstein 1980: 189). Utilising this old trope for her direct social commentary on the continuing plight of the working-class woman and the challenges she faces indicates the small amount of progress made during the century in the visibility of this problem. But by the fin de siècle, there was a new challenge to face: atheism.

As "a man utterly without religious feeling or hope in the Hereafter," (8) Gerard does not feel the need for a sanctioned marriage by the church. For Gerard, because there is no God, the Protestant belief in "the discipline of delayed gratification [... where] one had to make people believe that pleasure in this world must bring pain in the next" was of no concern (Watt 2008: 25), and allowed him to continue on his decadent and hedonistic self-destructive path. ${ }^{21}$ There are no negative consequences to Gerard's social standing if he follows his inclination and does not marry, while the sexual double standard means that Hester becomes a social pariah. She herself notes that "[a]ll the stories that she had ever read went

${ }^{21}$ Braddon here is subtly engaging with the free love movement that advocated the separation of state from sexual issues such as marriage, birth control and a woman's right to her own body (Jeffreys 1997: 83). The debate continued to grow after Gerard, with the publication of John Lane's "Keynote Series" that published George Egerton's Keynotes (1894) and Grant Allen's The Woman Who Did (1895), both of which are classed as decadent texts that had "unduly frank references to the physical side of marriage" (Harris 1968: 1408). For instance, in Egerton's "A Cross Line" the protagonist's unmarried servant has a baby who dies. The death is regarded as a warning to the heroine not to run off with her seducer, but at the same time the servant is not condemned - she's not dismissed. 
to prove that desertion was the inevitable end of forbidden bliss such as she has tasted" (307). ${ }^{22}$ Thus, while Gerard's atheism justifies his decadence to himself, Hester's downfall as collateral damage reveals that real-world judgement and ramifications are made more important in Braddon's rewriting of the Faust myth; Braddon asks her readership to consider the consequences of their actions in the absence of divine punishment.

Braddon's gender and religious politics seem to be conservative at this point, with Hester's narrative acting as a warning to those women who may follow the atheist philosophy. ${ }^{23}$ Braddon was religious herself, a "sensible, nofuss-about-it, Church-of-England Christian" (Wolff 1979: 266), with her diaries noting that she went to Church each Sunday, and sometimes mid-week. Nevertheless, in Goethe's text Gretchen drowns her baby, attempts suicide, and is then tried and found guilty of infanticide, while Braddon's Hester drowns her baby, attempts suicide, but is then exonerated; the baby's demise has the coroner's verdict "death by misadventure" (384), which "freed Hester from all shadow of blame in the child's death" (387). This transformation is a radical revision of the fallen woman plot, suggesting Braddon's text is an agitating force for social change in regards to women's lack of power and control over their own bodies and position within society. Thus, Braddon's Gerard, as a combination novel, involves not a harmonious mixture, but a collision of tropes and discourses to generate a radical commentary on her source texts.

In saving Hester, though, Braddon's rewriting damns Gerard. Gerard abandons Hester for Edith with "no tender allusion to that new obligation which the summer was to bring upon Hester and upon him" (325) - he knew she was with child. This is a significant difference from Goethe's text, as Faust did not know Gretchen was pregnant. Braddon holds Gerard directly culpable for Hester's downfall; the death of their child lies firmly at his door. Braddon's text is agitating for social reform: women should not be blamed for their 'fallen' status, for it is the men who tempt them who should be punished. Gerard is not saved like Goethe's Faust through female intervention; his illness finally kills him and it is up to the reader to decide about the afterlife and his fate.

Not only is Hester exonerated from killing their child, but she also subverts other fallen woman endings, such as that of Esther in Elizabeth Gaskell's Mary Barton (1848) or Tess in Hardy's Tess of the d'Urbervilles (1891) who both die at the end of their novels. Hester's positive narrative conclusion allows her to marry Gerard, the man she loves, be welcomed into his family circle and live to inherit

${ }^{22}$ As in other Braddon texts, Hester uses the novels she has read to inform her real-life situation. But while Isabel Gilbert in The Doctor's Wife (1864) is "not a woman of the world" because "of the world out of a three-volume romance she had no more idea than a baby" (Braddon [1864] 1998: 253), Hester's novel reading warns her of the challenges that lie ahead. This is the triumph of fiction's self-reflexivity and another instance of the open intertextual nature and the fictionality of fiction that comments on real life.

${ }^{23}$ Or indeed the path of the New Woman who was seeking radical change on the social, financial, and political position of women in the fin de siècle, as epitomised by Henrik Ibsen's plays A Doll's House (1879) and Hedda Gabler (1890). 
his fortune. Braddon is clearly championing the fallen woman whose "good name" is explicitly restored (420). However, the only way for Braddon to redeem Hester was for her to marry Gerard and conform to society's marital, moral and religious strictures. If read with a conservative eye, this reduces the power and impact of Braddon's social commentary. As a commercially successful writer, Braddon was still writing under the limitations of a patriarchy that controlled access to the market even if with this novel she was striving to "be ranked with Zola and rejected by Mudie" as the title to this article references.

\section{Conclusion}

While Marlowe's Doctor Faustus is "characterized by the positive, individualistic drives of the Renaissance" (Watt 2008: xiv), and Goethe's Faust states "Who can perceive God and then presume to say: 'I do not believe in him'?" (3435), Braddon's Gerard is driven by his own atheism and hedonism to "have it all," as characterised by the decadence of the 1890s. Part of the decadent literary movement with Ibsen, Wilde, and Corelli, Braddon's novel examined the moral pessimism of the fin de siècle as a result of increasing scientific knowledge and a decline in religious belief. Braddon's churchgoing and habit of writing on topical themes for the masses positioned her well for producing a novel that addressed these themes. In her rewriting of the Faust myth for her increasingly secular readership, Braddon's makes three significant contributions. Firstly, she transforms the supernatural Mephistopheles into a dandy hypnotist, precluding the need for divine judgement to reflect the decline in religious belief at the end of the nineteenth century, as well as warning readers of the dangers surrounding the scientific advancements of hypnotism. Secondly, she turns the magical talisman into a medical test that illustrates the perils of contemporary culture's bourgeois materialism, not only for society at large, but for the individual's physical and mental health. Thirdly, she updates the fallen woman plot to champion her, while also using Hester to illustrate the dangers women in particular faced with the emergence of atheism and the increase in immoral hedonistic behaviour. Thus, despite earlier criticism for rewriting texts, Braddon demonstrates the strengths and merits of a well-thought out and culturally updated rewriting of classic texts with an astute and modern understanding of the anxieties surrounding the material culture and decadence of the fin de siècle. 


\section{Bibliography}

Alexander, Lynn M. 2003. Women, Work and Representation: Needlewomen in Victorian Art and Literature. Athens: Ohio University Press.

Atkinson, Juliette. 2017. French Novels and the Victorians. Oxford: Oxford University Press.

Balzac, Honoré de. 1831 (2010). The Wild Ass's Skin (La Peau de Chagrin), translated by Helen Constantine. Oxford: Oxford University Press.

Beller, Anne-Marie. 2015. "'You're obliged to have recourse to bodies': Corporeal Proliferation, Class, and Literary Taste in M. E. Braddon's Revision of The Outcasts." in "Victorian Literature and the Aesthetic Impure," edited by Mariaconcetta Costantini. Special issue of English Literature, 2.2: 275-290. DOI: $10.46911 /$ HMTW2498

Bodley, Lorraine Byrne (ed.). 2017. Music in Goethe's Faust: Goethe's Faust in Music. Suffolk: Boydell Press.

Bogousslavsky, Julien, Olivier Walusinski and Denis Veyrunes. 2009. "Crime, Hysteria and Belle Époque Hypnotism: The Path Traced by Jean-Martin Charcot and Georges Gilles de le Tourette." European Neurology: History of Neurology, 64.4: 193-99.

Braddon, Mary Elizabeth. 1864 (1998). The Doctor's Wife, Oxford: Oxford University Press.

Braddon, Mary Elizabeth. 1891 (2009). Gerard; or, The World, The Flesh and The Devil. Leonaur.

Braddon, Mary Elizabeth and Robert Lee Wolff. 1974. "Devoted Disciple." Harvard Library Bulletin: 5-35, 129-61.

Brockett, Oscar Gross and Franklin Joseph Hildy. 2006. History of the Theatre. Boston, MA: Allyn and Bacon.

Carnell, Jennifer. 2000. The Literary Lives of M. E. Braddon. Hastings: Sensation Press.

Carnell, Jennifer and Law, Graham. 2000. "'Our author': Braddon in the Provincial Weeklies," in Beyond Sensation: Mary Elizabeth Braddon in Context, edited by Marlene Tromp, Pamela K. Gilbert and Aeron Haynie, Albany: State University of New York Press, 127-63.

Edelstein, T. J. 1980. "They Sang 'The Song of the Shirt': The Visual Iconology of the Seamstress." Victorian Studies, 23.2: 183-210. JSTOR, www.jstor.org/stable/ $\underline{3827085 .}$.

Ellis, Havelock. 1890. The Criminal. London: G. Bell \& Sons.

Federico, Annette. 2000. Idol of Suburbia: Marie Corelli and Late-Victorian Literary Culture. Virginia: University of Virginia Press.

Gagnier, Regenia. 1993. "On the Instability of Human Wants: Economic and Aesthic Man." Victorian Studies, 36.2: 125-153.

Garelick, Rhonda. 1998. Rising Star: Dandyism, Gender, and Performance in the Fin de Siecle. Princeton: Princeton University Press.

Goethe, Johhann Wolfgang von. 1808 (2007). Faust. Ware: Wordswoth.

Harris, Wendell V. 1968. "John Lane's Keynotes Series and the Fiction of the 1890's." PMLA, 83.5: 1407-13. 
Hatter, Janine. 2015. "Writing the Vampire: M. E. Braddon's 'The Good Lady Ducayne' and Bram Stoker's Dracula," in Supernatural in the Nineteenth Century, Supernatural Studies, Janine Hatter (ed.) 2.2, 29-47.

Hood, Thomas. 1843. "The Song of the Shirt." Punch, or the London Charivari. 16 December: n.p.

Jeffreys, Sheila. 1985 (1997). The Spinster and Her Enemies: Feminism and Sexuality, 1880-1930. North Melbourne, Australia: Spinifex Press.

Keating, Peter. 1996. "Introduction," Sorrows of Satan. Oxford: Oxford University Press. xiii-xx.

King, Andrew. 2009. "The Origins of Ouida's Pascarèl (1873): the Combination Novel, Myths of the Female Artist and the Commerce of Art." Anglistica Pisana, 1.2: 7786.

Kohl, Norbert. 2011. Oscar Wilde: the Works of a Conformist Rebel. Cambridge University Press.

Kucich, John and Jenny Bourne Taylor. 2012. The Oxford History of the Novel in English: Volume 3: The Nineteenth-Century Novel 1820-1880. Oxford: Oxford University Press.

Lang, Andrew. June 1887. "Literary Plagiarism." The Contemporary Review, 51: 831-40.

Lang, Andrew. November 1887. "Realism and Romance." The Contemporary Review, 52: 683-93.

Law, Graham. 2000. Serializing Fiction in the Victorian Press, Basingstoke: Palgrave.

"Literary Gossip." The Athenaeum, 26 September 1891. 3335: 420.

"Literature." Sporting Gazette, 14 October 1865: 786.

M. "French Novels." Belgravia: A London Magazine, 1867. 3: 78-82.

[Mansel, Henry Longueville]. 1863. "Sensation Novels." Quarterly Review, 113: 226: 481-514.

Matyjaszkiewicz, Krystyna. 1985. James Tissot, New York: Abbeville Press.

du Maurier, George. 1895 (1998). Trilby, Oxford: Oxford University Press.

"Miss Braddon's Latest Novel." The Athenaeum, 2 \& 9 April 1892. 3362 \& 3363: 448 \& 456.

“The Morning's News.” The Daily News, 5 September 1891: 5.

Oliphant, Margaret. 1862. "Sensation Novels." Blackwood's Edinburgh Magazine, 91.DLIX: 564-584.

Oliphant, Margaret. 1867. "Novels." Blackwood's Edinburgh Magazine, 102: 257-80.

“Our Library Table.” Bristol Mercury, 28 September 1891: 3.

"Our London Letter." Dundee Courier, 26 September 1891: 5.

"Planché's Extravaganzas." The Spectator, 20 March 1888. 53.2699: 372.

Potolsky, Matthew. 2013. The Decadent Republic of Letters: Taste, Politics, and Cosmopolitan Community from Baudelaire to Beardsley. Pennsylvania: University of Pennsylvania Press.

Potter, Paul. 1895 (1996). Trilby, adapted by Herbert Beerbohm Tree. Trilby and other Plays: Four Plays for Victorian Star Actors, (ed.) George Taylor. Oxford: Oxford University Press, 199-271. 
Rae, W. F. 1865. "Sensation Novelists: Miss Braddon." North British Review, 43: 180204.

Ritschel, Nelson O'Ceallaigh. 2017. Bernard Shaw, W. T. Stead, and the New Journalism: Whitechapel, Parenell, Titanic and the Great War. London: Palgrave Macmillan.

Schaffer, Talia. 2000. The Forgotten Female Aesthetes: Literary Culture in LateVictorian England. Virginia: University of Virginia Press.

Sears, Albert C. 2006. "Mary Elizabeth Braddon and the 'Combination Novel': The Subversion of Sensational Expectations in Vixen." Victorian Sensations: Essays on a Scandalous Genre, (eds.) Kimberly Harrison and Richard Fantina. Columbus: Ohio State University Press, 41-52.

"Second Children's Employment Commission Report." 1843. Parliamentary Papers, XIV.

Shaw, Arthur. 1960. Belafonte: An Unauthorized Biography. New York, NY: Chilton.

"Some Recent Novels." The Pall Mall Gazette, 1 March 1892: 3.

Symons, Arthur. 1893. "The Decadent Movement in Literature." Harper's New Monthly Magazine, 87, November: 858-67.

Waddle, Helen. 1932 (2000). The Wandering Scholars of the Middle Ages. Mineola, NY: Dover Publications.

Walbank, Alan F. (ed.). 1950. Queens of the Circulating Library: Selections from Victorian Lady Novelists, 1850-1900, London: Evans Brothers.

Wallace, Diana. 2009. “The Haunting Idea': Female Gothic Metaphors and Feminist Theory." The Female Gothic: New Directions, (eds.) Diana Wallace and Andrew Smith. Basingstoke: Palgrave Macmillan, 26-41.

Watt, Ian. 1996. Myths of Modern Individualism: Faust, Don Quixtoe, Don Juan, Robinson Crusoe. Cambridge: Cambridge Univeristy Press.

Weisberg, Barbara. 2004. Talking to the Dead: Kate and Maggie Fox and the Rise of Spiritualism, New York: HarperCollins

Wolff, Robert Lee. 1979. Sensational Victorian: The Life and Fiction of Mary Elizabeth Braddon. London: Garland. 